\title{
Frailty as a Predictor of Neurosurgical Outcomes in Brain Tumor Patients: A Systematic Review and Meta-Analysis
}

\author{
Jinfeng Zhu ( $\backsim$ Julia200204@163.com ) \\ Nanjing University Medical School Affiliated Nanjing Drum Tower Hospital https://orcid.org/0000-0002-0824-4195 \\ Qiuning Xu \\ Nanjing University Medical School Affiliated Nanjing Drum Tower Hospital \\ Fang Wang \\ Nanjing University Medical School Affiliated Nanjing Drum Tower Hospital \\ Ping Yuan \\ Nanjing University Medical School Affiliated Nanjing Drum Tower Hospital \\ Cuiling Ji \\ Nanjing University Medical School Affiliated Nanjing Drum Tower Hospital \\ Lu Chen \\ Nanjing University Medical School Affiliated Nanjing Drum Tower Hospital https://orcid.org/0000-0002-0170-8778
}

\section{Research Article}

Keywords: Brain tumor, frailty, neurosurgical outcomes, systematic review

Posted Date: August 26th, 2021

DOI: https://doi.org/10.21203/rs.3.rs-840145/v1

License: (c) (1) This work is licensed under a Creative Commons Attribution 4.0 International License. Read Full License 


\section{Abstract}

Purpose The object of this study is to describe the existing evidence and completed the first systematic review meta-analysis between frailty and neurosurgical outcomes in brain tumor patients. The primary outcome is mortality and postoperative complications, the second outcomes including readmission rate, discharge disposition, length of stay (LOS) and hospitalization costs.

Methods Seven English databases and four Chinese databases were searched to identify the neurosurgical outcomes and frailty among patients with brain tumor. With no restrictions on the publication period. According to the JBI manual for evidence synthesis and the PRISMA guidelines, two independent reviewers applied the Newcastle-Ottawa Scale (NOS) for cohort studies, the Joanna Briggs Institute (JBI) Critical Appraisal Checklist for Cross-Sectional Studies to evaluate the methodological quality of each study.

Results 13 papers included in the systematic review and prevalence of frailty ranged from $1.48 \%$ to $57 \%$. Frailty is significantly associated with increased the risk of mortality (OR,1.63; Cl,1.33-1.98; $\mathrm{P} \otimes 0.001)$, postoperative complications $\left(O R, 1.48 ; C l, 1.40-1.55 ; P \otimes 0.001 ; P^{2}=33 \%\right)$, non-routine discharge position than home $(O R, 1.72 ; C l, 1.41-2.11 ; P ख 0.001)$, prolonged LOS in brain tumor patients $(O R=1.25 ; C l=1.09-1.43 ; P=0.001)$ and higher hospitalization costs in brain tumor patients. But Frailty was not independently associated with readmission $(O R, 0.99 ; C l, 0.96-1.03 ; P=0.74)$

Conclusion Frailty is an independent predictor of mortality, postoperative complications, non-routine discharge position rate, LOS and hospitalization costs in brain tumor patients. Besides frailty has a significant potential role in risk stratification, preoperative shared decision-making and perioperative management.

\section{Introduction}

Histologically, brain tumor can be categorized into primary and metastatic tumors [1]. It is reported that the incidence of malignant brain tumors is $7.1 / 100,000$ and 13.8/100,00 for benign tumors [2]. Brain tumor could happen at any age and the most common reported in adults with median age of 59 [3] In addition, malignant brain tumor is the most common solid tumor of children with more than 4600 cases estimated in 2016 [2]. Moreover, brain tumor is the second highest level of symptom burden diseases in the world which is just after lung cancer although only account for $1.4 \%$ of all cancers [4-5]. It has been long recognized as producing a high rate of mortality and disability usually have a poor prognosis for survival with diverse physical, cognitive and behavioral impairments [5].The 5-year survival rate through the full age spectrum is just $34 \%$ on averages, and only $6.1 \%$ among the group of greater than 75 years old. Especially patients with glioblastoma are approximately $5 \%$, and the median survival of newly diagnosed glioblastoma ranges from less than 1 to 3 years, with an average of $12 \sim 14$ months [6-7].

As the population ages and increasing need for surgery, the role of risk stratification tools becomes critical to surgical planning. It has been shown the age is an important predictor of health status and cancer outcomes, but it is not the only factor to consider in perioperative planning [8]. Frailty describes a state of increased vulnerability and decreased physiological reserve that can be defined multidimensional components, including physical, psychological, and social factors [9]. The new concept of patient frailty in surgery, particularly complex surgical interventions including cranial neurosurgery makes frailty a concern in neurosurgical outcomes $[8,10]$. Patients with frailty are at a higher risk of poor health outcomes and frailty has been explored as a predictor of adverse events, such as perioperative complications, readmissions, falls, disability and mortality in many neurosurgical literature [11-12]. But so far, the precise relationship between frailty and brain tumor has not been previously established with certainty, preventing evidence-based advancements in neurosurgical management.

The object of this study is to describe the existing evidence and completed the first systematic review meta-analysis between frailty and neurosurgical outcomes in brain tumor patients. The primary outcome is mortality and postoperative complications, the second outcomes including readmission, discharge disposition, length of stay (LOS) and hospitalization costs.

\section{Methods}

This systematic review was designed based on guidelines from the Joanna Briggs Institute (JBI) [13], and was reported according to the Preferred Reporting Items for Systematic reviews and Meta-Analysis (PRISMA) guidelines [14] (Online Resource 1). The review is registered with the PROSPERO International Prospective Register of Systematic Reviews (registration number CRD42021248424) on 12 April,2021 and will end on December, 2021.We will continue to update any amendments on PROSPERO.

\section{Eligibility criteria}

\section{Study designs:}

Studies that provided observational data on cross-sectional or prospective associations between frailty and neurosurgical outcomes among patients with brain tumor were included. Besides, duplicate studies, abstracts, conference proceedings, comments, letters, correspondences, editorials, unavailability of full articles were excluded. Published in languages other than English and Chinese studies were excluded. Corresponding authors were contact if additional information is needed.

\section{Types of participants}


Patients confirm diagnosis of brain tumor at any age based on international criteria and guideline definitions, including intracranial metastatic from systematic cancers, brain neoplasms, cerebral tumor, glioma, meningioma, hypophysoma and pituitary tumor.

\section{Interest of context}

Frailty was be assessed using validated assessment instruments, such as the Johns Hopkins Adjusted Clinical Groups (JHACG) frailty-defining diagnoses indicator, Frail Index (FI), the modified Frailty Index ( $\mathrm{mFI}$ ), 5-factor Modified Frailty Index (mFI-5), the Hop-kins Frailty Score (HFS), et al.

\section{Types of outcome measures}

Studies that reported any neurosurgery outcomes were included. Such as mortality, postoperative complications, readmission, discharge disposition, length of stay (LOS) and hospitalization costs.

\section{Data Sources and Search Strategy}

Seven electronic databases included Web of Science, EMBASE, CINAHL, Scopus, MEDLINE, PubMed, the Cochrane Library and four Chinese databases included China National Knowledge Infrastructure, China Science and Technology Journal Database, Wanfang Database, and Chinese Biomedicine Literature Database were analyzed. The search was be limited in English and Chinese, with no restrictions on the publication period. After conducted the preliminary search of various databases to analyze the keywords and determine the index terms. The tailored search strategy was used on various databases to ensure that all available studies were obtained. Subsequently, the search was be modified according to different databases and was limited by the language of

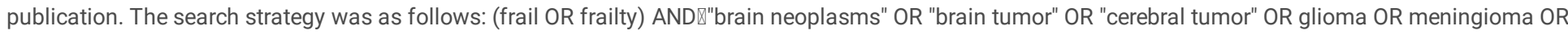
hypophysoma OR "pituitary tumor"). Online Resource 2 describes the search strategy of MEDLINE and Web of Science. Titles, abstracts, and full texts were screened and examined for eligibility independently by two investigators. Reference lists of relevant articles were reviewed for additional studies.

\section{Study selection}

Following the database search, all identified studies were collected, and duplicates were removed. Firstly, two independent reviewers screened the titles and abstracts, and then downloaded and read the full article according to the inclusion and exclusion criteria to assess eligibility. The documents screened and selected in each step were managed through the Note Express V.3.3.0 software.

\section{Data extraction}

The extracted data included specific details about the first author, published year, country, design, number of patients, type of patients, age, gender, frailty assessment, study period, prevalence of frailty, covariates and neurosurgical outcomes. The data was recorded in Microsoft Excel for analysis.

\section{Data analysis}

A random-effects or fixed-effects meta-analysis was used combine odds ratio $(O R)$ or hazard ratio $(R R)$ for categorical data and weighted mean differences for continuous data of neurosurgical outcomes. And $95 \%$ confidence intervals $(C l)$ calculated for analysis. Heterogeneity was statistically evaluated using Cochrane's Q statistic and $P^{2}$, and $P^{2}$ values of $25 \%, 50 \%$, and $75 \%$ were considered as low, moderate, and high heterogeneity, respectively. $P<0.05$ was considered statistically significant. The finding was described in narrative form including figures and tables if statistical pooling is not possible. All analysis was be performed on Review Manager version 5.3. (The Cochrane Collaboration)

\section{Assessment of methodological quality}

Risk of bias was assessed using the Newcastle-Ottawa Scale (NOS) [15] (Online Resource 3) for cohort studies, the Joanna Briggs Institute (JBI) Critical Appraisal Checklist [16] (Online Resource 4) for Cross-Sectional Studies to evaluate the methodological quality of each study. The NOS uses 2 tools for case control and cohort studies and encompasses 3 quality parameters: selection, comparability, and exposure/outcome assessment. It assigns a maximum of 4 points for selection, 2 points for comparability, and 3 points for exposure or outcome (for a total of up to 9 points). The NOS scores of 7 or higher were considered high-quality studies, and scores of 5 to 6 denoted moderate quality [15]. The Joanna Briggs Institute (JBI) Critical Appraisal Checklist included 11 items and each need to answers Yes, No, Unclear or Not/Applicable [16]. Two researchers appraised the articles independently, and any disagreement was discussed until a consensus was reached.

\section{Assessment of reporting bias}

The reporting bias was explored using a funnel plot if the included studies are more than 10. Risk of bias was assessed as visual inspection of a funnel plot constructed by plotting effect size versus SE. 


\section{Quality of evidence}

Quality assessment was conducted use the Grading of Recommendations Assessment, Development and Evaluation system [17]. Papers were ranked four categories-high, moderate, low, and very low.

\section{Results}

\section{Literature search process}

Papers identified through databases searching were 473 , and hand searching were 2 . After removed duplicated papers were 274 . Then excluded 225 papers by title and abstract, 36 papers by full-text screened. Finally, 13 papers included in the systematic review underwent assessed for eligibility. The selection process was summarized in a PRISMA flow diagram (Fig.1).

\section{Study characteristics}

This review included thirteen studies which designed eleven retrospective studies [18-21, 23-24, 26-30], one prospective study [22] and one retrospective crosssectional study [25] with sample sizes ranging from 76 to 115317 (Table 2). Publication location come from the United States [18-20, 22-30] and Columbia [21] between 2013 and 2021. Frailty was assessed use mFI [18,21,25,29-30], JHACG [19-20,27-28], HFS [22], mFI-5[23-24,26]. Prevalence of frailty ranged from $1.48 \%$ to $57 \%$.

\section{Risk of Bias}

12 studies [18-24,26-30] assessed using the NOS [15], the overall studies were high-quality with 9 scores of 7 studies [20,23-29], 8 scores of 3 studies $[18,22,30]$ and 7 scores of 2 studies [19,21] (Tables 2). According to the JBI critical appraisal checklist, the methodological quality one study [25] was strong with the score of 8 (Tables 3).

\section{Frailty as a predictor of neurosurgical outcomes}

\section{Frailty is significantly associated with the risk of mortality in brain tumor patients}

Seven studies included 30-day mortality subgroup reported frailty is significantly associated with increased risk of mortality in brain tumor patients (OR,1.63; $C l, 1.33-1.98 ; P \otimes 0.001)$. No significant difference in 60-day mortality and 90-day mortality subgroup between the two cohorts. However, the total outcome reported the same outcome of 30-day mortality (total OR,1.56; Cl,1.30-1.86; P凶0.001) (Fig.2).

\section{Frailty is significantly associated with the risk of postoperative complications in brain tumor patients}

Frailty is significantly associated with increased risk of postoperative complications in brain tumor patients as eleven studies reported (Fig.3). The cross metaanalysis of the fixed-effects $\left(O R, 1.48 ; C l, 1.40-1.55 ; P \otimes 0.001 ; P^{2}=33 \%\right)$ and random-effects $\left(O R, 1.48 ; C l, 1.37-1.60 ; P \otimes 0.001 ; P^{2}=33 \%\right)$ reported that there is little difference between the two models, the research results are reliable.

\section{Frailty is significantly associated with the risk of non-routine discharge position in brain tumor patients}

Eight studies reported discharge disposition as an outcome and the data shows frailty is significantly associated with increased the risk of non-routine

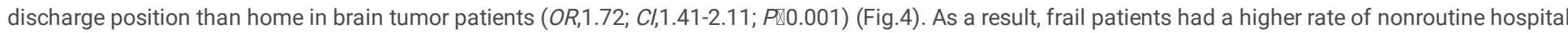
discharges compared to non-frail patients, which encompasses transfers to skilled nursing home facilities, short-term hospitals, and home health care.

\section{Frailty is significantly associated with the risk of readmission in brain tumor patients}

Readmissions were classified 30-day, 90-day, 180-day subgroup. Frail patients had lower 90-day readmission rates compared with non-frail patients (OR,0.94; $C l, 0.89-0.99 ; P \otimes 0.05)$. However, no difference was seen at the 30-day $(O R, 1.04 ; C l, 0.99-1.10 ; P=0.12)$ or 180 -day $(O R, 1.04 ; C l, 0.91-1.18 ; P=0.56)$ between the two cohorts. Frailty was not independently associated with readmission $(O R, 0.99 ; C l, 0.96-1.03 ; P=0.74)($ Fig.5).

\section{Frailty is significantly associated with longer LOS in brain tumor patients}


Four studies reported frailty prolonged LOS in brain tumor patients $(O R=1.25 ; C l=1.09-1.43 ; P=0.001)$ (Fig.6). Frailty is significantly increased the LOS in the studies by Asemota [19] (9.27 days [Cl,7.79-10.75] vs 4.46 days [Cl, 4.39-4.53], $P<0.001$ ), Bonney [20] (incident rate ratio, 1.92; $C l, 1.87-1.98 ; P<$

0.0001 ), Cloney [21] ( 6 days vs 4 days), Shahrestani1[27] (13.79 \pm 19.10 days vs $4.37 \pm 5.22$ days, $p<0.001)$. Shahrestani2[28] (16.1 \pm 13.9 days vs $9.0 \pm 8.1$ days, $P<0.0001)$. Theriault [29] found for every unit increase in the $\mathrm{mFl}$, the expected LOS increased by 1.678 days on average, holding other variables constant $(P=0.046)$.

\section{Frailty is significantly associated with higher hospitalization costs in brain tumor patients}

Frailty is significantly associated with higher hospitalization costs in brain tumor patients reported by Asemota $[19](\$ 109,614.33[C / \$ 92,756.09-\$ 126,472.50]$ vs $\$ 56,370.35[\mathrm{Cl} \$ 55,595.72-\$ 57,144.98], P<0.001)$, Shahrestani1[27] $(\$ 191,129.27 \pm \$ 244,619.10$ vs $\$ 89,269.91 \pm \$ 82,787.67, P<$

$0.001)$, Shahrestani2[28] $(\$ 39,114.69 \pm \$ 38,249.02$ vs $\$ 27,924.03 \pm \$ 23,886.26, P<0.0001)$.In addition, with each 1 -point increase in $\mathrm{mFl}-5$ score, total charges increased by $\$ 5846(C / \$ 3971-\$ 7721, P<0.001)[23]$.

\section{Assessment of reporting bias}

The effect size estimates for mortality (Fig.7) and complications (Fig.8) all fell within the pseudo 95\% confidence limits of the funnel plot. There are no large reported bias effects.

\section{Discussion}

This is the first systematic review and meta-analysis to report frailty as a predictor of neurosurgical outcomes in brain tumor patients. Neurosurgical outcomes not only include short-term but also include long-term outcomes. Frailty was found to be an independent risk factor for brain tumor patients of all ages, with increased adverse outcomes including mortality, non-routine discharge position rate, LOS and hospitalization costs, especially postoperative complications. This conclusion may be particularly important not only for elderly, but also for young patients diagnosed with brain tumors. Because physicians are used to thinking that age is an important predictor of complications, but in fact, frailty may be the strongest predictor. However, our review found there is no significant difference between frail and non-frail patients in readmission rate, particularly 30-day and 180-day readmission.

Prevalence of frailty ranged from 19.3-55.3\% using mFI, 41.3-57\% using mFI-5, 1.48-50.3\% using JHACG, and 25.4\% using HFS. Different assessment tools may differ slightly. One study demonstrated that the $\mathrm{mFI}$ is $>3$ times the rate of frailty compared to the JHACG method [30]. Although more than 12 of methods for frailty definition in the past 5 years, regardless, there remains limited instrument tools that specifically target the frailty of neurosurgical patients. Furthermore, the ideal instrument of frailty defined is more likely uses history and physical examination characteristics which is more objective, according to a correlation between examination-based and diagnosis-based instruments [31]. Therefore, this area warrants further exploration in the future.

The adverse outcomes associated with frailty were linked each other. For example, frailty patients have higher incidence of postoperative complications, which led to longer LOS, then increased total hospitalization costs. Additionally, postoperative medical and surgical complications also result in higher mortality. On the contrary, shorter LOS was associated with decreased fewer hospital-acquired infections, then led to lower complication rates, at the same time, decreased the hospitalization costs and then improved patient's satisfaction [32-33]. These association explained frailty could also serve as a useful risk adjustment tool which were related to hospital quality and reimbursement.

Given preoperative neurological deficits, neurosurgical oncology patients may be more heavily dependent on preoperative functional status than in other surgical populations [34]. As an independent risk factor for worse outcomes following brain tumor surgery, frailty has tremendous potential for risk stratification and outcome prediction. These allow frailty as a part of surgical risk-benefit assessment to underscore the utility of preoperative careening. Frailty should be stringently evaluated with multidisciplinary program prior to surgery, and it may aid clinical decision making [35-36]. Patients will also be considered to be unsuitable between surgery or other forms of management [37]. In addition, a frailty assessment could also lead to increase intraoperative and postoperative interdisciplinary treatment program and care pathway that targeting specific elements of frailty such as nutrition, mobilization, and hydration [38]. Especially benign brain tumor makes the majority of surgeries exclusively elective or at least nonurgent because of the slow or nongrowing nature of these tumors. This may give us opportunity to tailor preoperative interventions or pre-habilitation to optimize surgical readiness [39], which aimed at decreasing frailty and improve postoperative outcomes.

\section{Limitations}

There were limitations of this study. Because of the limitation article, our study failed to include all neurosurgical outcomes, such as some studies reported frail patients were more likely to undergo reoperations [19, 29]. Further, owning to the majority studies were retrospective design which included our systematic review, thus our analysis outcome may affect by the original study data contained in the database. Fortunately, our review included 13 studies and 257,822 brain tumor patients, the data came from large case volume across multiple healthcare settings and countries, which compensate the limitation and improve the accuracy of outcomes.

\section{Conclusions}

Frailty is an independent predictor of mortality, postoperative complications, non-routine discharge position rate, LOS and hospitalization costs in brain tumor patients. And frailty has a significant potential role in risk stratification, preoperative shared decision-making and perioperative management. Further study 
could be designed as prospective to explore the association between frailty and neurosurgical outcomes as well as quality-of-life.

\section{Declarations}

Funding

This work was supported by ["Six-One Project" Top-notch Talent Research Project of Jiangsu Provincial Health and Health Commission], grant number: [LGY2020012], and [2021 Graduate Research and Practice Innovation Program for Medical School of Nanjing University].

\section{Competing interests}

The authors declare that they have no competing interests.

\section{Availability of data and material}

All data generated or analysed during this study are included in this published article

\section{Code availability}

\section{Author's contributions}

Design of this systematic review protocol: JZ and LC; literature search, data extraction and appraisal, data synthesis and interpretation, manuscript drafting: JZ, FW and QX; data selection, data appraisal, data synthesis, manuscript critical revision, and arbitrate in cases of disagreement: JZ, FW, PY and CJ. All the authors have read, provided feedback, and approved the final manuscript.

\section{Ethics approval}

Not applicable

This review only uses secondary data, ethical approval is not required. No other ethical issues are foreseen.

\section{Consent to participate}

Not applicable

\section{Consent for publication}

Not applicable

\section{Acknowledgements}

None

\section{References}

1. Louis DN, Perry A, Reifenberger G et al (2016) The 2016 World Health Organization classification of tumors of the Central Nervous System: a summary. Acta Neuropathol 131:803-820. https://doi.org/10.1007/s00401-016-1545-1

2. Vargo MM (2017) Brain tumors and metastases. Phys Med Rehabil Clin N Am 28:115-141. https://doi.org/10.1016/j.pmr.2016.08.005

3. Ostrom QT, Cioffi G, Gittleman H et al (2019) CBTRUS statistical report: primary brain and other central nervous system tumors diagnosed in the United States in 2012-2016. Neuro Oncol 21: v1-100. https://doi.org.10.1093/neuonc/noz150

4. Global Burden of Disease Cancer Collaboration, Fitzmaurice C, Abate D et al (2019) Global, regional, and national cancer incidence, mortality, years of life lost, years lived with disability, and disability-adjusted life-years for 29 cancer groups, 1990 to 2017: A systematic analysis for the global burden of disease Study. JAMA Oncol 5:1749-1768. https://doi.org/10.1001/jamaoncol.2019.2996

5. Lidstone V, Butters E, Seed P et al (2003) Symptoms and concerns amongst cancer outpatients: identifying the need for specialist palliative care. Palliat Med 17:588-595. https://doi.org.10.1191/0269216303pm814oa

6. McNeill KA (2016) Epidemiology of brain tumors. Neurol Clin 34: 981-998. https://doi.org.10.1016/j.ncl.2016.06.014 
7. Ostrom QT, Cote DJ, Ascha M et al (2018) Adult glioma incidence and survival by race or ethnicity in the United States from 2000 to 2014 . JAMA Oncol 4:1254-1262. https://doi.org/10.1001/jamaoncol.2018.1789

8. Arya S, Long CA, Brahmbhatt R et al (2016) Preoperative frailty increases risk of nonhome discharge after elective vascular surgery in home-dwelling patients. Ann Vasc Surg 35:19-29. https://doi.org.10.1016/j.avsg.2016.01.052

9. Fried LP, Tangen CM, Walston J et al (2001) Frailty in older adults: evidence for a phenotype. J Gerontol A Biol Sci Med Sci 56(3): M146-M156. https://doi.org.10.1093/gerona/56.3.m146

10. Makary MA, Segev DL, Pronovost PJ et al (2010) Frailty as a predictor of surgical outcomes in older patients. J Am Coll Surg 210:901-908. https://doi.org.10.1016/j.jamcollsurg.2010.01.028

11. Clegg A, Young J, lliffe S et al (2013) Frailty in elderly people. Lancet 381(9868):752-762. https://doi.org.10.1016/S0140-6736(12)62167-9

12. Ensrud KE, Ewing SK, Cawthon PM et al (2009) A comparison of frailty indexes for the prediction of falls, disability, fractures, and mortality in older men. $J$ Am Geriatr Soc 57(3): 492-498. https://doi.org.10.1111/j.1532-5415.2009.02137.x

13. Aromataris E, Munn Z (Editors) (2020) JBI Manual for Evidence Synthesis. JBI 2020. https://doi.org.10.46658/JBIMES-20-01. Available from https://synthesismanual.jbi.global

14. Moher D, Liberati A, Tetzlaff J et al (2009) Preferred reporting items for systematic reviews and meta-analyses: the PRISMA statement. Plos Med 6: e1000097. https://doi.org.10.1371/journal.pmed.1000097

15. Wells GA, Shea B, O'Connell J et al (2013) The Newcastle-Ottawa scale (NOS) for assessing the quality of nonrandomised studies in meta-analysis. Available from http://www.ohri.ca/programs/clinical_epidemiology/oxford.asp

16. Moola S, Munn Z, Tufanaru C et al (2020) Chap. 7: Systematic reviews of etiology and risk. In: Aromataris E, Munn Z (Editors). JBI Manual for Evidence Synthesis. JBI. https://doi.org/10.46658/JBIMES-20-08. Available from https://synthesismanual.jbi.global

17. Balshem H, Helfand M, Schünemann HJ et al (2011) GRADE guidelines: 3. Rating the quality of evidence. J Clin Epidemiol 64:401-406. https://doi:10.1016/j.jclinepi.2010.07.015

18. Adams P, Ghanem T, Stachler R et al (2013) Frailty as a predictor of morbidity and mortality in inpatient head and neck surgery. JAMA otolaryngologyhead neck surgery 139:783-789. https://doi.org/10.1001/jamaoto.2013.3969

19. Asemota AO, Gallia L (2019) Impact of frailty on short-term outcomes in patients undergoing transsphenoidal pituitary surgery. Journal of neurosurgery 132:360-370. https://doi.org/10.3171/2018.8.JNS181875

20. Bonney PA, Chartrain AG, Briggs RG et al (2021) Frailty is associated with in-hospital morbidity and nonroutine disposition in brain tumor patients undergoing craniotomy. World neurosurgery 146:e1045-e1053. https://doi.org/10.1016/j.wneu.2020.11.083

21. Cloney M, D'Amico R, Lebovic J et al (2016) Frailty in Geriatric Glioblastoma Patients: A predictor of operative morbidity and outcome. World neurosurgery 89:362-367. https://doi.org/10.1016/j.wneu.2015.12.096

22. Harland TA, Wang M, Gunaydin D et al (2020) Frailty as a predictor of neurosurgical outcomes in brain tumor patients. World neurosurgery 133 :e813e818. https://doi.org/10.1016/j.wneu.2019.10.010

23. Huq S, Khalafallah AM, Jimenez AE et al (2020) Predicting postoperative outcomes in brain tumor patients with a 5-factor modified frailty Index. Neurosurgery 88:147-154. https://doi.org/10.1093/neuros/nyaa335

24. Khalafallah AM, Huq S, Jimenez AE et al (2020) The 5-factor modified frailty index: an effective predictor of mortality in brain tumor patients. Journal of neurosurgery 1-9. https://doi.org/10.3171/2020.5.JNS20766

25. Pitts KD, Arteaga AA, Stevens BP et al (2019) Frailty as a predictor of postoperative outcomes among patients with head and neck cancer. Otolaryngology-head neck surgery: official journal of American Academy of Otolaryngology-Head Neck Surgery 160:664-671. https://doi.org/10.1177/0194599818825466

26. Sastry RA, Pertsch NJ, Tang 0 et al (2020) Frailty and outcomes after craniotomy for brain tumor. Journal of clinical neuroscience: official journal of the Neurosurgical Society of Australasia 81:95-100. https://doi.org/10.1016/j.jocn.2020.09.002

27. Shahrestani S, Ballatori AM, Chen XT et al (2020) Analysis of modifiable and nonmodifiable risk factors in patients undergoing pituitary surgery. Journal of neurosurgery 1-8. https://doi.org/10.3171/2020.4.JNS20417

28. Shahrestani S, Lehrich BM, Tafreshi AR et al (2020) The role of frailty in geriatric cranial neurosurgery for primary central nervous system neoplasms. NeuroSurg Focus 49:E15. https://doi.org/10.3171/2020.7.FOCUS20426

29. Theriault BC, Pazniokas J, Adkoli AS et al (2020) Frailty predicts worse outcomes after intracranial meningioma surgery irrespective of existing prognostic factors. NeuroSurg Focus 49:E16. https://doi.org/10.3171/2020.7.FOCUS20324

30. Youngerman BE, Neugut Al, Yang J et al (2018) The modified frailty index and 30-day adverse events in oncologic neurosurgery. Journal of neurooncology 136:197-206. https://doi.org/10.1007/s11060-017-2644-0

31. Segal JB, Chang H-Y, Du Y et al (2017) Development of a claims-based frailty Indicator anchored to a well-established frailty phenotype. Med Care 55:716-722. https://doi.org/10.1097/MLR.0000000000000729

32. Chin KR, Coombs AV, Seale JA (2015) Feasibility and patient-reported outcomes after outpatient single-level instrumented posterior lumbar interbody fusion in a surgery center: preliminary results in 16 patients. Spine (Phila Pa 1976) 40:E36-E42. https://doi.org/10.1097/BRS.0000000000000604

33. Gaujal L, Renou M, Dujaric ME et al (2016) First outpatient satisfaction questionnaire with day-surgery in a French comprehensive cancer center. Bull Cancer 103:330-335. https://doi.org/10.1016/j.bulcan.2016.01.018

34. Krivosheya D, Prabhu SS, Weinberg JS et al (2016) Technical principles in glioma surgery and preoperative considerations. J Neurooncol 130:243-252. https://doi.org/10.1007/s11060-016-2171-4

Page 7/15 
35. Axley MS, Schenning KJ (2015) Preoperative cognitive and frailty screening in the geriatric surgical patient: A narrative review. Clin ther 37:2666-2675. https://doi.org/10.1016/j.clinthera.2015.10.022

36. Nidadavolu LS, Ehrlich AL, Sieber FE et al (2020) Preoperative Evaluation of the Frail Patient. Anesth Analg 130:1493-1503. https://doi.org/10.1213/ANE.0000000000004735

37. Revenig LM, Canter DJ, Taylor MD et al (2013) Too frail for surgery? Initial results of a large multidisciplinary prospective study examining preoperative variables predictive of poor surgical outcomes. J Am Coll Surg 217:665-670.e1. https://doi.org/10.1016/j.jamcollsurg.2013.06.012

38. Gill TM, Baker DI, Gottschalk M et al (2003) A prehabilitation program for physically frail community-living older persons. Arch Phys Med Rehabil 84:394404. https://doi.org/10.1053/apmr.2003.50020

39. de Labra C, Guimaraes-Pinheiro C, Maseda A et al (2015) Effects of physical exercise interventions in frail older adults: a systematic review of randomized controlled trials. BMC Geriatr 15:154. https://doi.org/10.1186/s12877-015-0155-4

\section{Tables}

Table 1

Characteristics of included studies 


\begin{tabular}{|c|c|c|c|c|c|c|c|c|c|}
\hline $\begin{array}{l}\text { Study } \\
\text { (year) }\end{array}$ & Country & Design & $\begin{array}{l}\text { No. of } \\
\text { patients }\end{array}$ & Type of patients & $\begin{array}{l}\text { Median age } \\
\text { (range) years }\end{array}$ & $\begin{array}{l}\text { Gender } \\
\text { (\% women) }\end{array}$ & $\begin{array}{l}\text { Frailty } \\
\text { assessment }\end{array}$ & Study period & $\begin{array}{l}\text { Preva } \\
\text { of fra }\end{array}$ \\
\hline $\begin{array}{l}\text { Adams } \\
{[18]} \\
2013\end{array}$ & America & $\begin{array}{l}\text { Retrospective } \\
\text { study }\end{array}$ & 6727 & $\begin{array}{l}\text { Inpatients who } \\
\text { underwent } \\
\text { operations }\end{array}$ & 54.7 & $49.7 \%$ & $\mathrm{mFI}$ & $\begin{array}{l}\text { The NSQIP } \\
\text { participant } \\
\text { use files for } \\
\text { the period } \\
2005 \\
\text { through2010 }\end{array}$ & $49.7 \%$ \\
\hline $\begin{array}{l}\text { Asemota } \\
\text { [19] } \\
2019\end{array}$ & America & $\begin{array}{l}\text { Retrospective } \\
\text { study }\end{array}$ & 115317 & $\begin{array}{l}\text { Pituitary tumors } \\
\text { or disorders } \\
\text { who had } \\
\text { undergone } \\
\text { transsphenoidal } \\
\text { pituitary surgery }\end{array}$ & 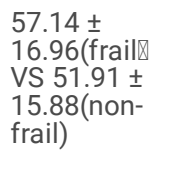 & $50.9 \%$ & JHACG & $\begin{array}{l}\text { The } \\
2000 \sim 2014 \\
\text { National } \\
\text { (Nationwide) } \\
\text { Inpatient } \\
\text { Sample }\end{array}$ & $1.48 \%$ \\
\hline $\begin{array}{l}\text { Bonney } \\
{[20]} \\
2021\end{array}$ & America & $\begin{array}{l}\text { Retrospective } \\
\text { study }\end{array}$ & 87835 & $\begin{array}{l}\text { Patients } \\
\text { undergoing } \\
\text { craniotomy for } \\
\text { brain tumors }\end{array}$ & $\begin{array}{l}\geq 65 \rrbracket 57 \% \\
\text { (frail) VS } \\
45.1 \% \text { (non- } \\
\text { frail) }\end{array}$ & $53.0 \%$ & JHACG & $\begin{array}{l}\text { The } \\
\text { Nationwide } \\
\text { Readmissions } \\
\text { Database } \\
\text { from } \\
2010 \sim 2014\end{array}$ & $8.2 \%$ \\
\hline $\begin{array}{l}\text { Cloney } \\
\text { [21] } \\
2016\end{array}$ & Columbia & $\begin{array}{l}\text { Retrospective } \\
\text { study }\end{array}$ & 243 & $\begin{array}{l}\text { Geriatric } \\
\text { patients who } \\
\text { underwent } \\
\text { resection of } \\
\text { glioblastoma, } \\
\text { including } \\
\text { reoperation for } \\
\text { recurrent } \\
\text { disease. }\end{array}$ & $73.1 \pm 5.5$ & None & $\mathrm{mFI}$ & $\begin{array}{l}\text { Columbia } \\
\text { University } \\
\text { Medical } \\
\text { Center New } \\
\text { York } \\
\text { Presbyterian } \\
\text { Hospital from } \\
2000 \text { to } 2012\end{array}$ & $19.3 \%$ \\
\hline $\begin{array}{l}\text { Harland } \\
\text { [22] } \\
2020\end{array}$ & America & $\begin{array}{l}\text { Prospective } \\
\text { study }\end{array}$ & 260 & $\begin{array}{l}\text { patients } \geq 18 \\
\text { years old } \\
\text { scheduled for } \\
\text { elective } \\
\text { resection of } \\
\text { tumor }\end{array}$ & $\begin{array}{l}56.1 \text { (frail) VS } \\
50.6 \text { (non- } \\
\text { frail) }\end{array}$ & $\begin{array}{l}53 \% \text { (frail) VS } \\
41 \% \text { (non-frail) }\end{array}$ & HFS & $\begin{array}{l}\text { The University } \\
\text { of Colorado } \\
\text { over a 3-year } \\
\text { period } \\
\text { (October } 2014 \\
\text { to August } \\
2017 \text { ). }\end{array}$ & $25.4 \%$ \\
\hline
\end{tabular}

\begin{tabular}{|c|c|c|c|c|c|c|c|c|c|}
\hline $\begin{array}{l}\text { Huq } \\
\text { [23] } \\
2021\end{array}$ & America & $\begin{array}{l}\text { Retrospective } \\
\text { cohort study }\end{array}$ & 1692 & $\begin{array}{l}\text { Brain tumor } \\
\text { patients who } \\
\text { underwent } \\
\text { primary surgery }\end{array}$ & 55.5 & $52 \%$ & $\mathrm{mFI}-5$ & $\begin{array}{l}\text { At a single } \\
\text { institution } \\
\text { between } \\
\text { January } \\
1,2017 \text { and } \\
\text { December } 31 \text {, } \\
2018 \text {. }\end{array}$ & $57 \%$ \\
\hline $\begin{array}{l}\text { Khalafallah } \\
\text { [24] } \\
2020\end{array}$ & America & $\begin{array}{l}\text { Retrospective } \\
\text { cohort study }\end{array}$ & 1692 & $\begin{array}{l}\text { Adult patients } \\
\text { who were } \\
\text { operated on for } \\
\text { brain tumors }\end{array}$ & $\begin{array}{l}55.49 \pm \\
15.22\end{array}$ & $52.3 \%$ & $\mathrm{mFI}-5$ & $\begin{array}{l}\text { At a single } \\
\text { institution } \\
\text { between } \\
\text { January 1, } \\
\text { 2017, and } \\
\text { December 31, } \\
2018\end{array}$ & None \\
\hline $\begin{array}{l}\text { Pitts } \\
\text { [25] } \\
2019\end{array}$ & America & $\begin{array}{l}\text { Retrospective } \\
\text { cross- } \\
\text { sectional } \\
\text { study }\end{array}$ & 410 & $\begin{array}{l}\text { Patients } \\
\text { presenting to an } \\
\text { academic } \\
\text { hospital } \\
\text { following a } \\
\text { surgical } \\
\text { procedure for a } \\
\text { head and neck } \\
\text { cancer } \\
\text { diagnosis }\end{array}$ & $61.9 \pm 10.5$ & $26 \%$ & $\mathrm{mFI}$ & $\begin{array}{l}\text { Between } \\
\text { January } \\
\\
2014 \text { and } \\
\text { December } \\
2017\end{array}$ & $42.2 \%$ \\
\hline $\begin{array}{l}\text { Sastry } \\
{[26]} \\
2020\end{array}$ & America & $\begin{array}{l}\text { Retrospective } \\
\text { cohort study }\end{array}$ & 20,333 & $\begin{array}{l}\text { Adult patients } \\
\text { undergoing } \\
\text { elective cranial } \\
\text { surgery for } \\
\text { tumor }\end{array}$ & $\begin{array}{l}54.85 \pm \\
12.11\end{array}$ & $55.76 \%$ & $\mathrm{mFl}-5$ & $\begin{array}{l}2012-2018 \\
\text { NSQIP } \\
\text { Participant } \\
\text { Use File }\end{array}$ & $41.3 \%$ \\
\hline
\end{tabular}




\begin{tabular}{|c|c|c|c|c|c|c|c|c|c|}
\hline $\begin{array}{l}\text { Shahrestani1[27] } \\
2020\end{array}$ & America & $\begin{array}{l}\text { Retrospective } \\
\text { cohort study }\end{array}$ & 746 & $\begin{array}{l}\text { Patients } \\
\text { undergoing } \\
\text { microscopic or } \\
\text { endoscopic } \\
\text { resection of a } \\
\text { Pituitary } \\
\text { adenomas }\end{array}$ & $\begin{array}{l}63.7 \text { (frail) VS } \\
63.5 \text { (non- } \\
\text { frail) }\end{array}$ & $41.6 \%$ VS $38.3 \%$ & JHACG & $\begin{array}{l}\text { The } 2016 \text { and } \\
2017 \text { National } \\
\text { Readmission } \\
\text { Database }\end{array}$ & None \\
\hline $\begin{array}{l}\text { Shahrestani2[28] } \\
2020\end{array}$ & America & $\begin{array}{l}\text { Retrospective } \\
\text { cohort study }\end{array}$ & 13342 & $\begin{array}{l}\text { Geriatric } \\
\text { patients } \\
\text { receiving } \\
\text { cranial } \\
\text { neurosurgery } \\
\text { for a primary } \\
\text { CNS neoplasm }\end{array}$ & $73.7 \pm 6.2$ & $45.2 \%$ & JHACG & $\begin{array}{l}\text { Between } 2010 \\
\text { and } 2017 \text { by } \\
\text { using the } \\
\text { Nationwide } \\
\text { Readmission } \\
\text { Database }\end{array}$ & $50.3 \%$ \\
\hline $\begin{array}{l}\text { Theriault } \\
{[29]} \\
2020\end{array}$ & America & $\begin{array}{l}\text { Single-center } \\
\text { retrospective } \\
\text { cohort study }\end{array}$ & 76 & $\begin{array}{l}\text { Patients who } \\
\text { underwent } \\
\text { intracranial } \\
\text { meningioma } \\
\text { resection }\end{array}$ & $55.8 \pm 15.3$ & $72.6 \%$ & $\mathrm{mFI}$ & $\begin{array}{l}\text { At } \\
\text { Westchester } \\
\text { Medical } \\
\text { Center in } \\
\text { Valhalla } \\
\text { between } \\
\text { August } 2012 \\
\text { and May } \\
2018\end{array}$ & $55.3 \%$ \\
\hline $\begin{array}{l}\text { Youngerman } \\
\text { [30] } \\
2018\end{array}$ & America & $\begin{array}{l}\text { Retrospective } \\
\text { cohort study }\end{array}$ & 9149 & $\begin{array}{l}\text { Patients who } \\
\text { underwent } \\
\text { neurosurgical } \\
\text { procedures for } \\
\text { intracranial } \\
\text { neoplasms }\end{array}$ & $\begin{array}{l}<45: 22.6 \% \\
45- \\
54: 20.8 \% \\
55- \\
64: 26.5 \% \\
\geq 65: 30.1 \%\end{array}$ & $52.9 \%$ & $\mathrm{mFI}$ & $\begin{array}{l}2008-2012 \\
\text { NSQIP } \\
\text { Participant } \\
\text { Use File }\end{array}$ & $48.5 \%$ \\
\hline
\end{tabular}

mFI=Modified Frailty Index; mFI-5=5-factor Modified Frailty Index; JHACG=The Johns Hopkins Adjusted Clinical Groups; HFS=The Hop-kins Frailty Score; NSC Program; ASA=American Society of Anesthesiologists; LOS=Lengths of Hospital Stay; KPS=Karnofsky Performance Status; BMI=Body Mass Index; CCI=Charl systemmFI=Modified Frailty Index; $\mathrm{mFI}$-5=5-factor Modified Frailty Index; JHACG=The Johns Hopkins Adjusted Clinical Groups; HFS=The Hop-kins Frailty Scc Program; ASA=American Society of Anesthesiologists; LOS=Lengths of Hospital Stay; KPS=Karnofsky Performance Status; BMI=Body Mass Index; CCI=Charl system

Table 2

Quality assessment of studies using the Newcastle-Ottawa Scale 


\begin{tabular}{|c|c|c|c|c|c|c|c|c|c|c|}
\hline \multirow[t]{2}{*}{ Study } & \multirow[t]{2}{*}{ Year } & \multicolumn{4}{|l|}{ Selection } & \multirow{2}{*}{$\begin{array}{l}\text { Comparability } \\
\text { Comparability } \\
\text { of cohorts on } \\
\text { the basis of } \\
\text { design or } \\
\text { analysis } \\
\text { (variables) }\end{array}$} & \multicolumn{3}{|l|}{ Outcome } & \multirow{2}{*}{$\begin{array}{l}\text { To } \\
\text { sc }\end{array}$} \\
\hline & & $\begin{array}{l}\text { Representative } \\
\text { of the exposed } \\
\text { cohort }\end{array}$ & $\begin{array}{l}\text { Selection } \\
\text { of the } \\
\text { non- } \\
\text { exposed } \\
\text { cohort }\end{array}$ & $\begin{array}{l}\text { Ascertainment } \\
\text { of exposure to } \\
\text { implants }\end{array}$ & $\begin{array}{l}\text { Demonstrate } \\
\text { that } \\
\text { outcome of } \\
\text { interest was } \\
\text { not present } \\
\text { at start of } \\
\text { study }\end{array}$ & & $\begin{array}{l}\text { Assessment } \\
\text { of outcome }\end{array}$ & $\begin{array}{l}\text { Was } \\
\text { follow-up } \\
\text { long } \\
\text { enough } \\
\text { for } \\
\text { outcomes } \\
\text { to occur }\end{array}$ & $\begin{array}{l}\text { Adequacy } \\
\text { of follow- } \\
\text { up of } \\
\text { cohorts }\end{array}$ & \\
\hline Adams[18] & 2013 & 1 & 1 & 1 & 1 & 1 & 1 & 0 & 1 & 8 \\
\hline Asemota[19] & 2019 & 1 & 1 & 1 & 0 & 2 & 1 & 0 & 1 & 7 \\
\hline Bonney [20] & 2021 & 1 & 1 & 1 & 1 & 2 & 1 & 1 & 1 & 9 \\
\hline Cloney[21] & 2016 & 1 & 1 & 1 & 1 & 1 & 1 & 0 & 1 & 7 \\
\hline Harland[22] & 2020 & 1 & 1 & 1 & 1 & 2 & 1 & 0 & 1 & 8 \\
\hline Huq[23] & 2021 & 1 & 1 & 1 & 1 & 2 & 1 & 1 & 1 & 9 \\
\hline Khalafallah[24] & 2020 & 1 & 1 & 1 & 1 & 2 & 1 & 1 & 1 & 9 \\
\hline Sastry[26] & 2020 & 1 & 1 & 1 & 1 & 2 & 1 & 1 & 1 & 9 \\
\hline Shahrestani1[27] & 2020 & 1 & 1 & 1 & 1 & 2 & 1 & 1 & 1 & 9 \\
\hline Shahrestani2[28] & 2020 & 1 & 1 & 1 & 1 & 2 & 1 & 1 & 1 & 9 \\
\hline Theriault[29] & 2020 & 1 & 1 & 1 & 1 & 2 & 1 & 1 & 1 & 9 \\
\hline Youngerman[30] & 2018 & 1 & 1 & 1 & 1 & 2 & 1 & 0 & 1 & 8 \\
\hline
\end{tabular}

Table 3

Quality assessment of studies using the Joanna Briggs Institute (JBI) Critical Appraisal Checklist

\begin{tabular}{|c|c|c|c|c|c|c|c|c|c|c|}
\hline study & year & $\begin{array}{l}\text { Were the } \\
\text { criteria for } \\
\text { inclusion in } \\
\text { the sample } \\
\text { clearly } \\
\text { defined? }\end{array}$ & $\begin{array}{l}\text { Were the } \\
\text { study } \\
\text { subjects and } \\
\text { the setting } \\
\text { described in } \\
\text { detail? }\end{array}$ & $\begin{array}{l}\text { Was the } \\
\text { exposure } \\
\text { measured in } \\
\text { a valid and } \\
\text { reliable } \\
\text { way? }\end{array}$ & $\begin{array}{l}\text { Were objective, } \\
\text { standard } \\
\text { criteria used } \\
\text { for } \\
\text { measurement } \\
\text { of the } \\
\text { condition? }\end{array}$ & $\begin{array}{l}\text { Were } \\
\text { confounding } \\
\text { factors } \\
\text { identified? }\end{array}$ & $\begin{array}{l}\text { Were } \\
\text { strategies to } \\
\text { deal with } \\
\text { confounding } \\
\text { factors } \\
\text { stated? }\end{array}$ & $\begin{array}{l}\text { Were the } \\
\text { outcomes } \\
\text { measured } \\
\text { in a valid } \\
\text { and reliable } \\
\text { way? }\end{array}$ & $\begin{array}{l}\text { Was } \\
\text { appropriate } \\
\text { statistical } \\
\text { analysis } \\
\text { used? }\end{array}$ & $\begin{array}{l}\text { Total } \\
\text { score }\end{array}$ \\
\hline Pitts[25] & 2019 & Yes & Yes & Yes & Yes & Yes & Yes & Yes & Yes & 8 \\
\hline
\end{tabular}

\section{Figures}




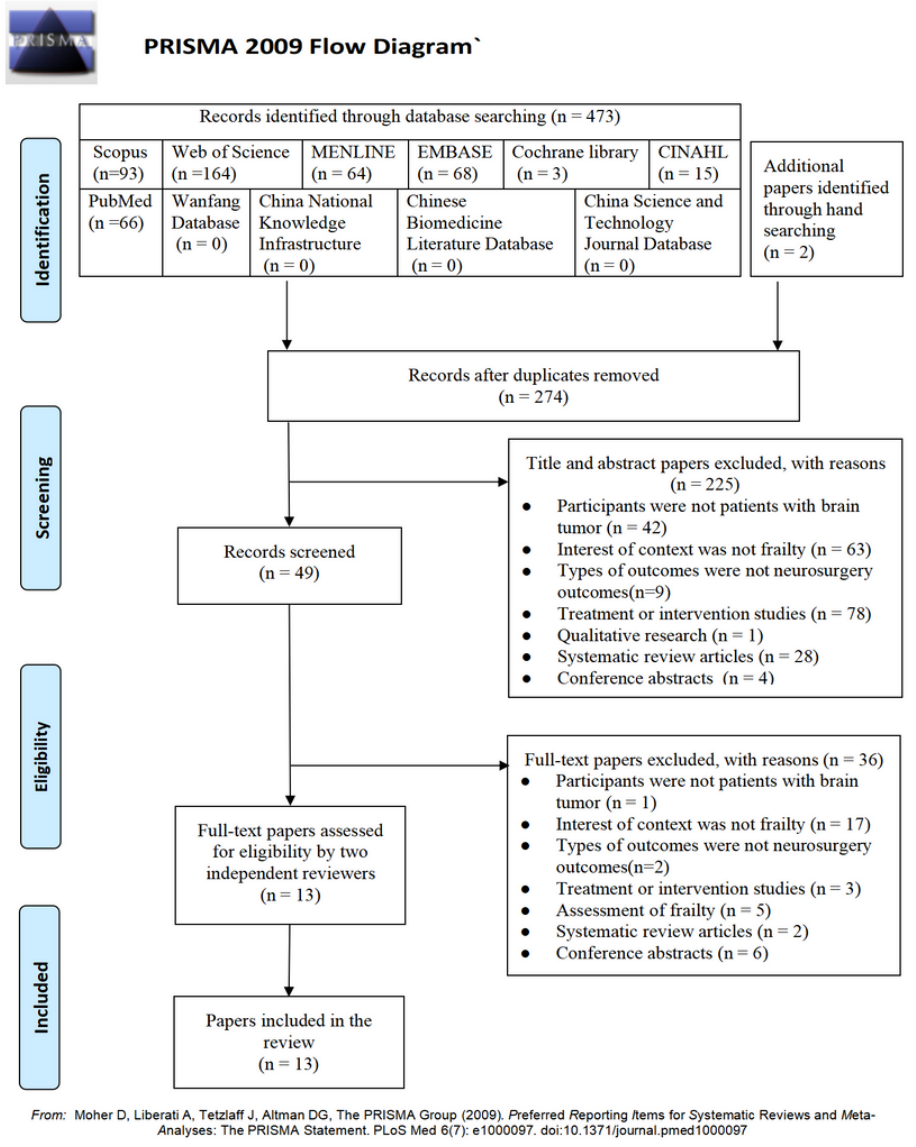

For more information, visit www.prisma-statement.org.

\section{Figure 1}

PRISMA flow diagram of literature search and study selection

Odds Ratio Odds Ratio

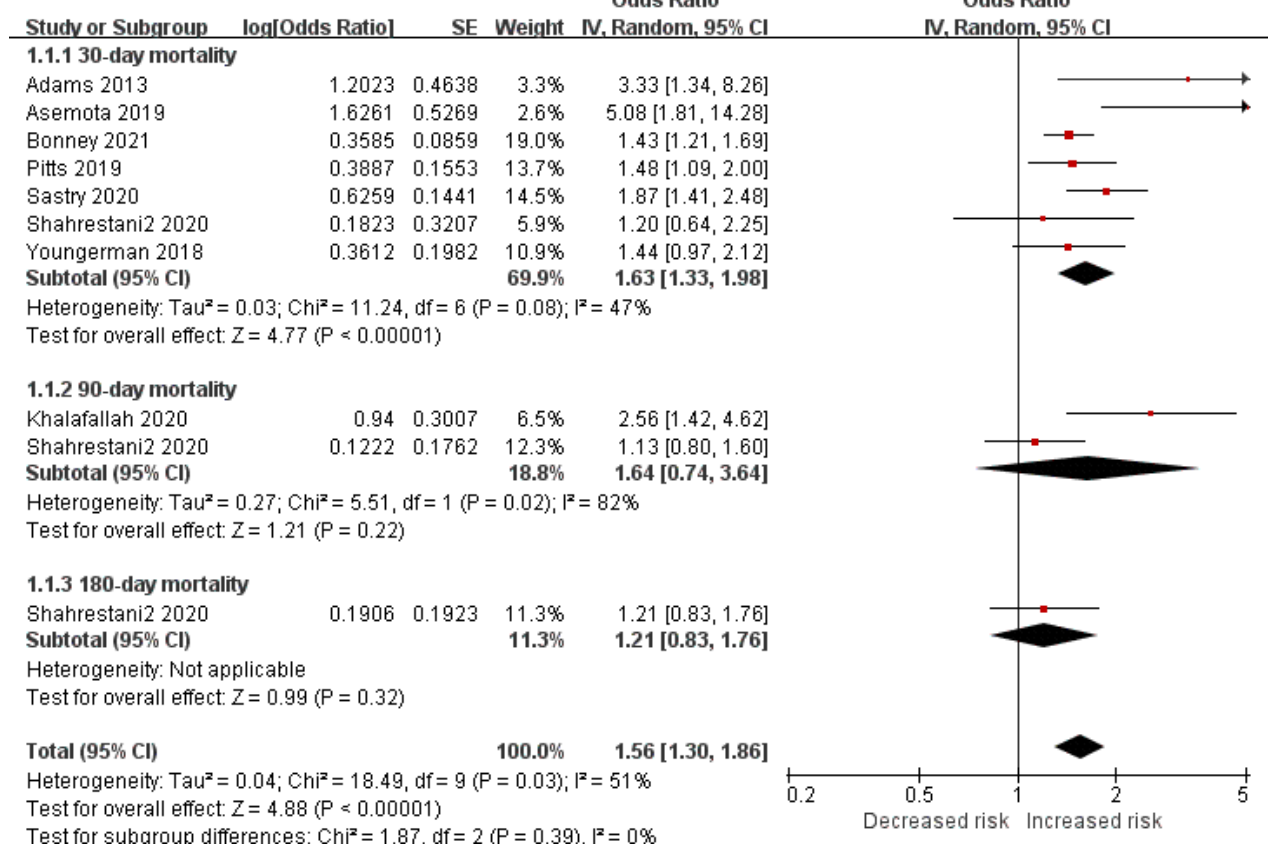

\section{Figure 2}

Forest plots presenting frailty is the risk of mortality in brain tumor patients 


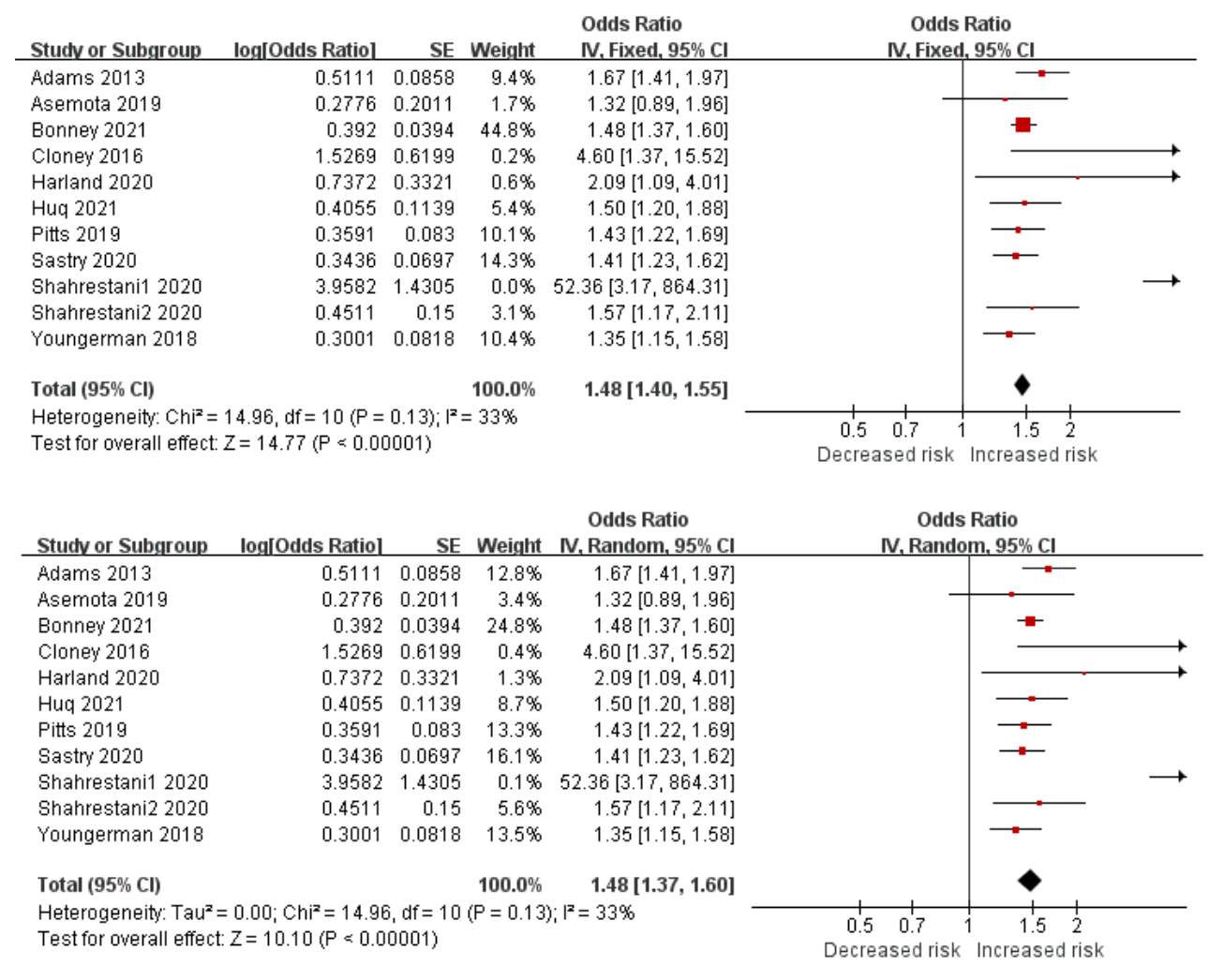

\section{Figure 3}

Forest plots presenting frailty is the risk of complications in brain tumor patients

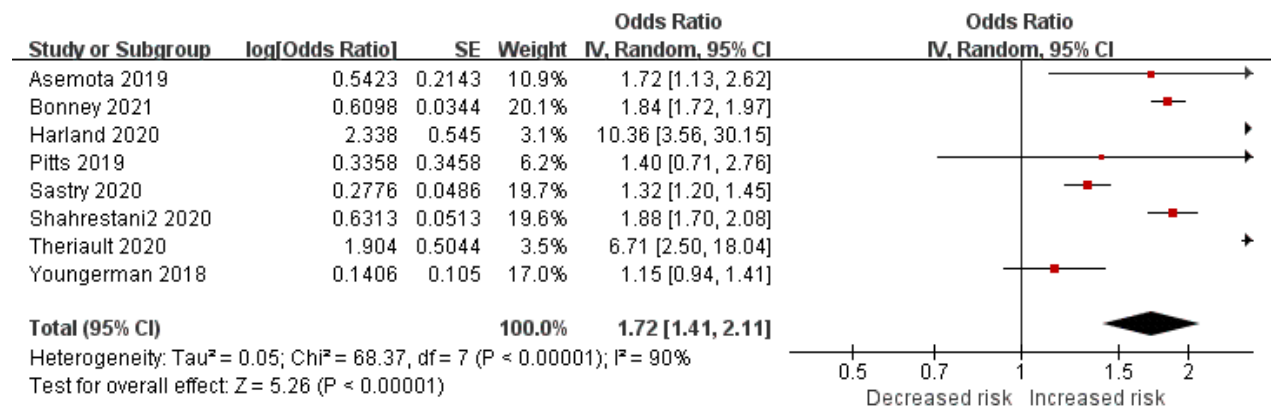

\section{Figure 4}

Forest plots presenting frailty is the risk of non-routine discharge disposition in brain tumor patients 


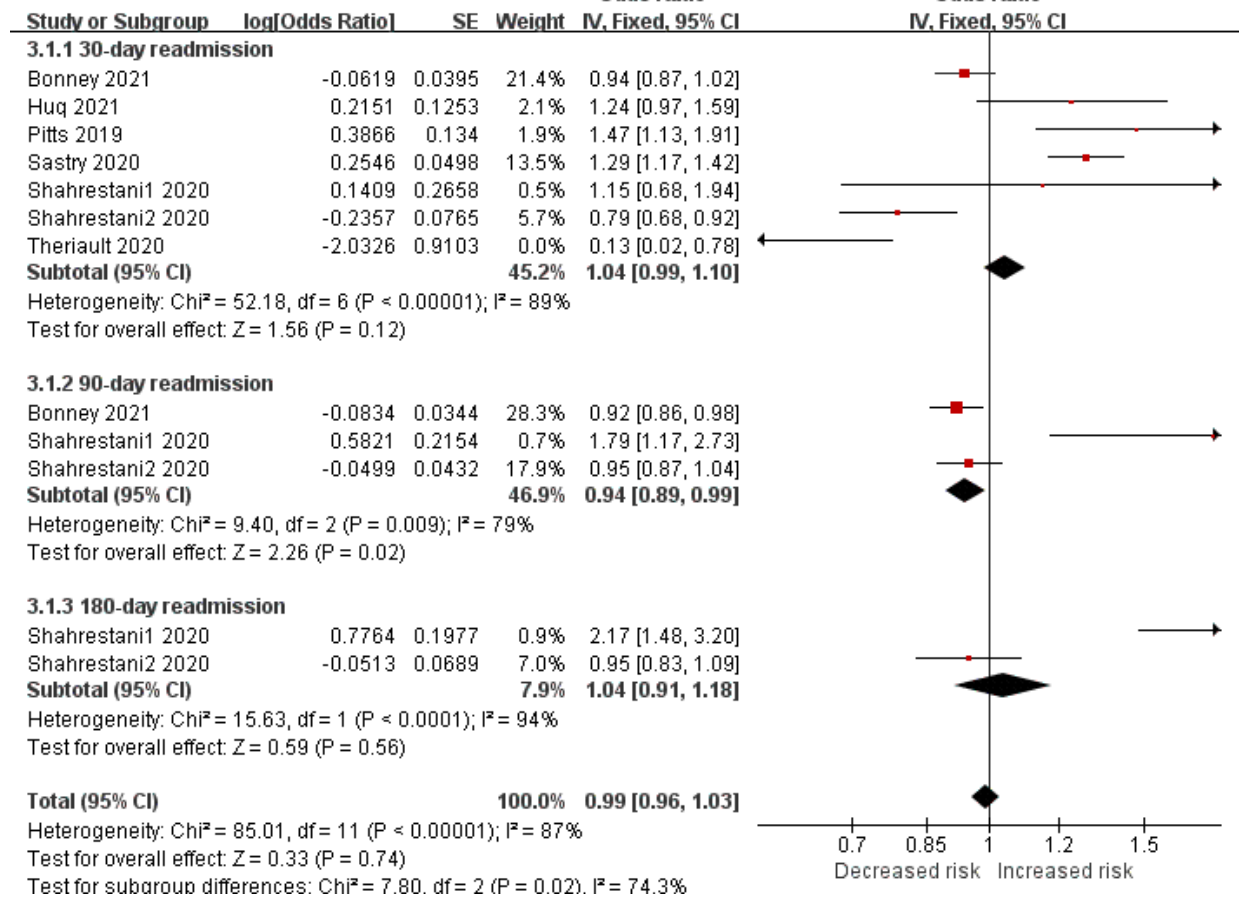

\section{Figure 5}

Forest plots presenting frailty is the risk of readmission in brain tumor patients

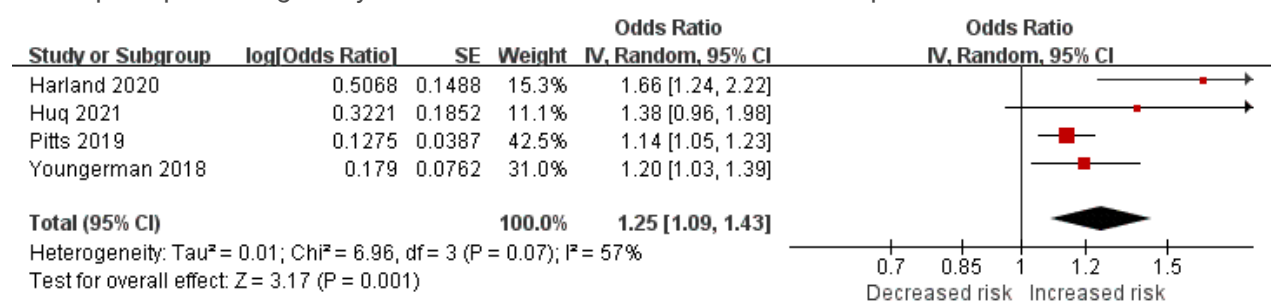

\section{Figure 6}

Forest plots presenting frailty is the risk of LOS in brain tumor patients

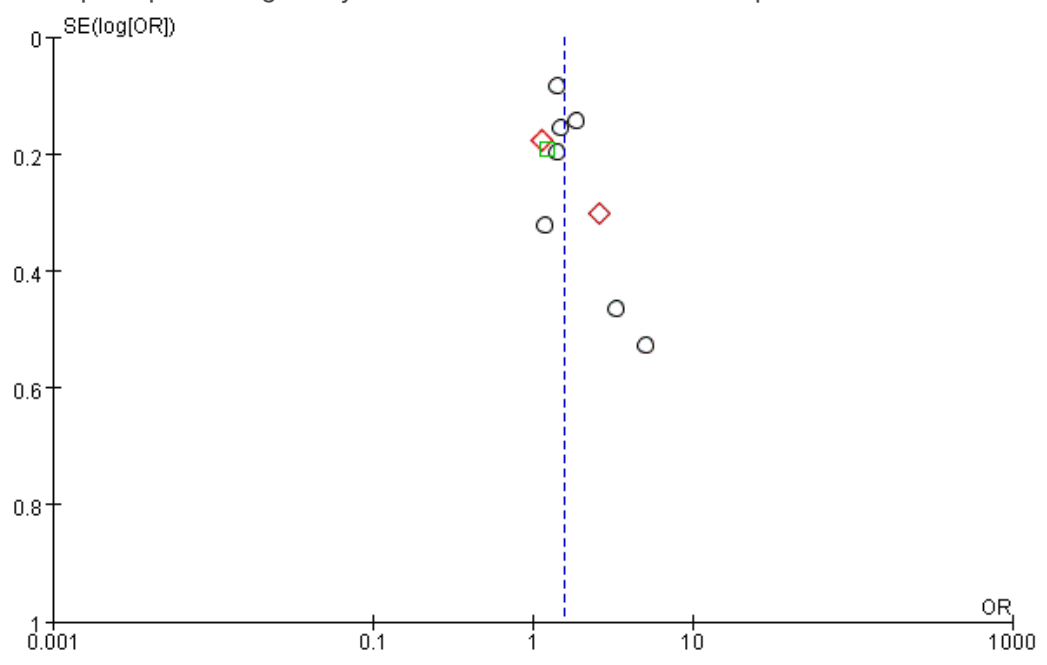

${ }_{0}^{\text {Subgroups }} \longrightarrow$-day mortality $\diamond$ 90-day mortality $\quad \square$ 180-day mortality

\section{Figure 7}

Funnel plots assessing for report bias of frailty on mortality in brain tumor patients 

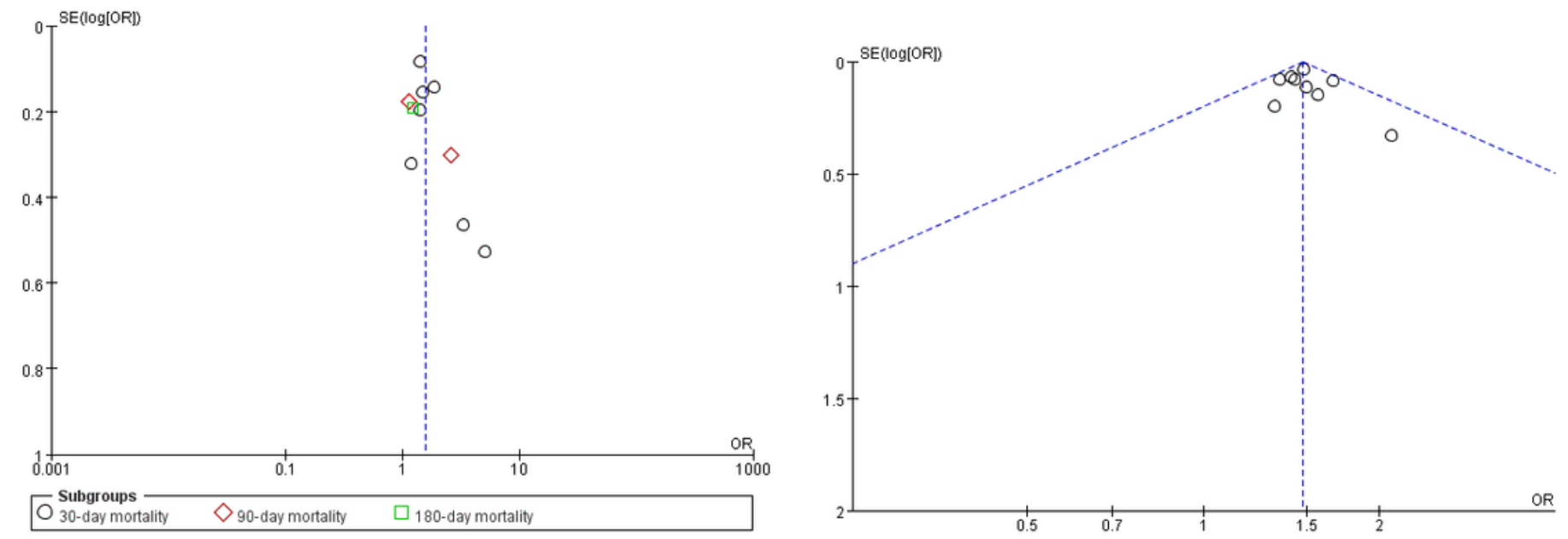

\section{Figure 8}

Funnel plots assessing for report bias of frailty on complications in brain tumor patients

\section{Supplementary Files}

This is a list of supplementary files associated with this preprint. Click to download.

- OnlineResource1PRISMA2020checklist.pdf

- OnlineResource2SearchStrategy.pdf

- OnlineResource3NewcastleOttawaScaleNOS.pdf

- OnlineResource4JBICriticalAppraisalChecklist.pdf 